Letter to the Editor

\title{
Mianserin abuse in psychiatric out-patients. A comment
}

\author{
UF Malt \\ Department of Psychosomatic Medicine, The National Hospital, 0027 Oslo, Norway
}

In a recent paper, Theret et al (1992) presented two cases of what they considered to be mianserin abuse. The patients had benzodiazepine and alcohol dependence. During treatment, which included tapering of benzodiazepine and alcohol restriction, both patients were prescribed $60 \mathrm{mg}$ of mianserin although the patients self increased the dosage to 120 and $150 \mathrm{mg}$ a day in order to obtain an 'anti-anxiety effect'. In the discussion, the authors refer to a recommended dose range of $30-90 \mathrm{mg} /$ day and state that "the pattern of drug consumption in these observations was abuse, not lack of compliance or selfmedication"'.

In my opinion, 'abuse' is not a likely explanation. Mianserin has in fact been suggested to be of particular value in the treatment of withdrawal symptoms and drug addiction (Pinder, 1991) and the doses used in the two cases are appropriate according to Scandinavian standards (Eitinger et al, 1991).

Mianserin is an alfa-2 adrenoreceptor antagonist and the drugs also have antagonistic effects on the $5-\mathrm{HT}_{1},{ }_{2}$ and ${ }_{3}$ receptors, the histaminergic $\mathrm{H}_{1}$ and $\mathrm{H}_{2}$ receptors and alfa-1 adrenoreceptors. Alfa-2-receptor antagonists have antidepressant effects and $5-\mathrm{HT}_{2}$ antagonists are known to have antidysthymic and anxiolytic effects. 5-HT antagonists have antiemetic effects. Accordingly, the combination of the alfa-2-adrenoreceptor and serotonergic receptor antagonism may be of particular value in the treatment of the two cases beyond the sleep improving effects of the drug.

In Norway, the most recent textbook on psychiatry recommends mianserin in doses of $60-$ $120 \mathrm{mg}$ in general practice. In institutions and in the hands of psychiatrists, "the double of this dose or more may be necessary" (Eitinger et al, 1991, p 171). The most influential Scandinavian textbook of psychopharmacology recommends to increase the mianserin dose to $120-150 \mathrm{mg}$ when necessary if the patient does not have unacceptable side effects (Lingjâerde, 1988). The dose range in more recent double-blind studies has been from 30-150 mg with mean (!) efficient mianserin doses between 100-130 mg (Feighner et al, 1983; Carman et al, 1991). Thus, the doses chosen by the two patients reported in the case histories were related to good clinical practice in Scandinavia!

In conclusion, from a Scandinavian perspective, the two cases presented by our French colleagues suggest nothing but the possible usefulness of mianserin in the course of detoxification of patients with drug and alcohol dependence.

\section{References}

Carman JS, Ahdieh H, Wyatt-Knowies E, Warga E, Panagides J (1991) A controlled study of mianserin in moderately to severely depressed outpatients. Psychopharmacol Bull 27, 135-139

Eitinger L, Retterst $\varnothing$ I N, Dahl AA, Malt UF (1991) Kriser og nevroser (Crises and neuroses). Scandinavian University, Oslo

Feighner JP, Jacobs RS, Jackson RE, Hendrickson G, Merideth CH, O'Meara P (1983) A double-blind comparative trial with mianserin and amitriptyline in outpatients with major depressive disorders. $\mathrm{Br} J$ Clin Pharmacol 15, 227s-237s

Lingjaerde O (1988) Psykofarmaka (Psychopharmacologic drugs). Oslo, Tano

Pinder RM (1991) Mianserin: pharmacological and clinical correlates. Nord Psykiatr Tidsskr 45 (suppl 24) 13-36

Theret L, Bertholon F, Germain MC (1992) Two cases of mianserin abuse in psychiatric out-patients. Eur Psychiatry $7,143-144$ 